\title{
Variations of Bacterial and Archaeal Community Structure and Diversity Along Soil Profiles in a Peatland in Southwest China
}

Wei Li

Yunnan University

Mingmo Luo

Yunnan University

Rui Shi

Yunnan University

Defeng Feng ( $\square$ fengdf@caf.ac.cn )

Chinese academy of Forestry

Zhenan Yang

China West Normal University

Huai Chen

Chengdu Institute of Biology

Bin $\mathrm{Hu}$

Yunnan University

\section{Research Article}

Keywords: soil stoichiometry, wetland, diversity, community, MiSeq

Posted Date: April 26th, 2021

DOl: https://doi.org/10.21203/rs.3.rs-413372/v1

License: (c) (i) This work is licensed under a Creative Commons Attribution 4.0 International License.

Read Full License

Version of Record: A version of this preprint was published at Environmental Science and Pollution Research on August 7th, 2021. See the published version at https://doi.org/10.1007/s11356-021-157746. 


\section{Abstract}

As bacteria and archaea are key components in the ecosystem, their alterations along soil profiles are important in understanding the biogeochemical cycles in peatland. However, little is known about the vertical distribution patterns of bacteria and archaea along the Bitahai peatland, as well as their relationship to soil chemical properties. Here, sequencing of 16S rRNA genes (Illumina, MiSeq) was used to analyze bacterial and archaeal abundance, diversity, and composition across $0-100 \mathrm{~cm}$ of the soil. Soil $\mathrm{pH}$, total $\mathrm{C}, \mathrm{N}$, and $\mathrm{P}$ concentrations and stoichiometric ratios also were estimated. Results revealed that total $\mathrm{C}$ and total $\mathrm{N}$ contents, as well as $\mathrm{C}: \mathrm{P}$ and $\mathrm{N}: \mathrm{P}$ ratios, significantly increased with increasing peatland depths, while total P decreased. The top three dominant phyla were Proteobacteria (39.64\%), Acidobacteria (12.93\%), and Chloroflexi (12.81\%) in bacterial communities, and were Crenarchaeota (58.67\%), Thaumarchaeota (14.34\%), and Euryarchaeota (10.82\%) in archaeal communities in the Bitahai peatland, respectively. The total relative abundance of the methanogenic groups and ammonia-oxidizing microorganisms all significantly decreased with soil depths. Both bacterial and archaeal diversity were greatly affected by the soil depths. Soil C, N, and P concentrations and stoichiometric ratios markedly impacted the community structure and diversity just in archaea, not in bacteria. Therefore, these results highlighted that the microbial community structure and diversity depended on soil depths, and the affecting factors for bacteria and archaea were different in the peatlands.

\section{Introduction}

Peatlands cover only about $3 \%$ of the earth's land area while storing nearly $30 \%$ of the global soil carbon (Dise 2009). Peatlands are an important carbon sink due to their low rate of organic matter decomposition and high water table (Laiho 2006). Carbon accumulated in the northern, tropical, and southern peatlands are 547, 50, and $15 \mathrm{Gt} C$ respectively (Yu et al. 2010). Carbon storage in peat soils is so high that carbon cycling in peatland ecosystems plays an important role in global carbon cycling. Microbial communities, as important decomposers, play key role in the carbon cycle of peatlands and in the overall ecosystem functioning. They do not only directly control the turnover of organic carbon but also benefit nutrient mineralization and uptake (Andersen et al. 2013). Carbon and nitrogen cycling are inextricably linked, and several studies have confirmed emissions of greenhouse gas $\mathrm{N}_{2} \mathrm{O}$ (Dinsmore et al. 2009; Saari et al. 2013), $\mathrm{CH}_{4}$ (Godin et al. 2012) and $\mathrm{CO}_{2}$ (Hoyt et al. 2019) from the peatlands. Soil microbes are related to the production of $\mathrm{N}_{2} \mathrm{O}, \mathrm{CH}_{4}$ and $\mathrm{CO}_{2}$ ( $\mathrm{Liu}$ et al. 2020b), therefore revealing their vertical distribution patterns would improve our understandings of nitrogen and carbon cycling in peatlands.

Peatland soil microbial communities in the surface and subsurface layers (Cadillo-Quiroz et al. 2006; Seward et al. 2020) have been well studied; however, studies regarding communities in deeper peat layers are relatively lacking (Putkinen et al. 2009; Zhou et al. 2017). Currently known peatland soil profiles are often from meters deep, and deeper layer soil microbial communities could be specialized for their own circumstances and thus may be distinct from the surface communities (Blume et al. 2002; Eilers et al. 2012; Tsitko et al. 2014). Many kinds of functional microbials involved in the carbon and nitrogen cycles 
of anaerobic processes widely exist in peatlands such as methanogenic archaea (Godin et al. 2012), methane anaerobic oxidizing bacteria (Zhu et al. 2012), ammonia-oxidizing microorganisms (Xu et al. 2019), and anaerobic ammonia oxidizing bacteria (Liu et al. 2020a). Therefore, studying the vertical distributions of soil microbial groups across deep soil profiles may have significance in understanding of the underlying mechanisms of carbon and nitrogen cycling in the peatlands.

Soil C, N, and P contents and stoichiometry vary with depths (Hu et al. 2019), therefore, under-standing how variations in physicochemical characteristics along the soil profile shape microorganism communities is essential to understanding the below-ground ecological processes. Previous studies revealed that soil microbial communities are determined by several abiotic factors (Andersen et al. 2013; Jeanbille et al. 2016), such as carbon, nitrogen and phosphorus contents (Koranda et al. 2011; Li et al. 2014; Wang et al. 2020) and C: N: P stoichiometry (Ren et al. 2016; Shen et al. 2019). For peatlands microbial communities, soil C:N ratio (Lin et al. 2014), pH, total organic carbon, total nitrogen, water table (Wang et al. 2019; Zhong et al. 2017), redox condition (Martinez et al. 2007), and carbon quality (Lamit et al. 2017) were factors that affecting microbial communities. However, control-ling factors of microbial communities and their functions across vertical sampling every $10 \mathrm{~cm}$ to the depth of $100 \mathrm{~cm}$ remains poor understood. Likewise, there is little information available on how the magnitude of variation in bacteria, archaea, methanogens and ammonia-oxidizing microorganisms within a deeper soil profile.

The Bitahai peat bog, located in the core of the Hengduan Mountain, is a globally important wetland. Many studies have focused on this wetland due to its important role in the construction of regional ecosystem services and ecological security barriers. Studies on this wetland mainly focus on land-use changes (Wu et al. 2015), diversity (He et al. 2019; Shu et al. 2013; Zhou and Chen 2006), phytophthora species (Huai et al. 2013), basic chromosome numbers of the genus Streptopus (Zhang and Gu 2005), and soil nutrient and nitrous oxide flux (Wang et al. 2017). However, its belowground soil microbial communities, which play enormous roles in driving the soil biogeochemistry cycles, are rarely studied.

The studying the differences between bacterial and archaeal communities along the peat profile and linking this to the changes in soil properties are important in the Bitahai peatland. Thus, our hypothesis was that: (1) bacterial and archaeal composition and diversity vary with soil depths and (2) soil properties affect the bacterial and archaeal communities and diversity along soil profiles in the Bitahai peatland.

\section{Materials And Methods}

\subsection{Site description and soil sampling}

The study site is located in the Bitahai Nature Reserve $\left(27^{\circ} 46-27^{\circ} 57^{\prime} \mathrm{N}, 99^{\circ} 54^{\prime}-100^{\circ} 09^{\prime} \mathrm{E}\right)$, Yunnan Province, Southwest China. The elevation in this region is $3512.9 \mathrm{~m}$, and has a cold and humid plateau climate with an annual average temperature of $5.4^{\circ} \mathrm{C}$. The hottest and coldest months are July and January, respectively, with average temperatures of 13.2 and $-3.8^{\circ} \mathrm{C}$, respectively. The annual average 
precipitation is $617.6 \mathrm{~mm}$ and occurs from around June to September. Our sampling sites are distributed on the typical peat bog wetland of Bitahai, which has a soil type of peat bog soil. The peat is saturated all the year round and the peat thickness is about $3 \mathrm{~m}$ deep. Major vegetations in this site are Carex lehmanii, Sanguisorba filiformis, Deschampsia cespitosa, and Sinocarum coloratum. Three sampling plots were set in this site during the 2017 growing season, and ten soil depths $(0-10 \mathrm{~cm}, 10-20 \mathrm{~cm}, 20-$ $30 \mathrm{~cm}, 30-40 \mathrm{~cm}, 40-50 \mathrm{~cm}, 50-60 \mathrm{~cm}, 60-70 \mathrm{~cm}, 70-80 \mathrm{~cm}, 80-90 \mathrm{~cm}$, and $90-100 \mathrm{~cm}$ ) were collected from each plot. Three replicate cores (ca., $100 \mathrm{~g}$ soil) were taken at each plot using a soil sampler device (diameter $52 \mathrm{~mm}$, Eijkelkamp, Netherlands). Roots and stones were careful removal by hand and sieved through by $2 \mathrm{~mm}$ for each soil core. A total of 30 soil samples were obtained and then stored in sterilized and sealed polyethylene packages, transported on ice to the laboratory, and stored at $-20^{\circ} \mathrm{C}$ until processing.

\subsection{Soil properties analysis}

Soil pH was determined using a pH meter (Orion 868 , USA) with a soil-to-water ratio of 1:2.5; total carbon (TC) was measured using a Vario TOC instrument manufactured by Elementar Company; total nitrogen (TN) and total phosphate (TP) were determined by $\mathrm{H}_{2} \mathrm{SO}_{4}$ digestion and was then measured using a Continuous Flow Analytic System (SEAL Analytical AA3, Germany).

\subsection{DNA extraction, PCR amplification and MiSeq sequencing}

Soil total DNA was extracted using the E.Z.N.A. ${ }^{\text {TM }}$ Soil DNA Kit (Omega Bio-tek, Inc., GA, USA) according to manufacturer's instructions and was collected in $50 \mu$ l of elution buffer. DNA concentration was determined using a NanoDrop One (Thermo Scientific, Wilmington). The 16S rRNA genes of the bacteria (515F: GTG CCA GCM GCC GCG GTAA and 926R: CCG YCA ATT YMT TTR AGT TT) and archaea (Arch519F: 5'- CAG CCG CCG CGG TAA-3' and Arch915R: 5'-GTG CTC CCC CGC CAA TTC CT-3') were amplified in triplicate (Vissers et al. 2010; Walters et al. 2016). The primers were tailed with sequences to incorporate Illumina adapters with indexing barcodes. A 50- $\mu$ l PCR mix consists of $25 \mu$ l Taq-Mix, $2.5 \mu l$ of each primer, $5 \mu$ template and $15 \mu \mathrm{ddd}_{2} \mathrm{O}$. PCR was performed under the following conditions: a 3-min initial denaturation step at $94^{\circ} \mathrm{C}$ followed by 30 thermal cycles of $30 \mathrm{~s}$ at $94^{\circ} \mathrm{C}, 30 \mathrm{~s}$ at $50^{\circ} \mathrm{C} / 57^{\circ} \mathrm{C}$ (annealing temperature $50^{\circ} \mathrm{C}$ and $57^{\circ} \mathrm{C}$ for $515 \mathrm{~F} / 926 \mathrm{R}$ and Arch519/Arch915R respectively), $40 \mathrm{~s}$ at $72^{\circ} \mathrm{C}$, and then a $10-\mathrm{min}$ incubation at $72^{\circ} \mathrm{C}$. The DNA concentrations were quantified, and the amplicons from each sample were pooled with an equimolar concentration for sequencing on an Illumina MiSeq Sequencer (San Diego, CA, United States).

\subsection{Processing of sequencing data}

The raw sequence data were processed and analyzed using the QIIME Pipeline (Caporaso et al. 2012). Briefly, sequencing reads with an average quality value $\leq$ Q20 were obtained, and ambiguous nucleotides in barcodes and homopolymer reads longer than $8 \mathrm{bp}$ and shorter than $150 \mathrm{bp}$ were removed to improve sequence quality. Paired ends were joined with FLASH (Magoc and Salzberg 2011), whereas the chimeric sequences were detected and eliminated using the USEARCH function in QIIME (Caporaso et al. 2010). 
After quality control and chimeric sequence removal, a total of 886,894 bacterial $16 \mathrm{~S}$ rRNA genes and 789,965 archaeal high quality gene sequences were obtained for community analyses of the 30 soil samples. The number of sequences per sample ranged from 7,597 to 34,181 , with an average of 29,563 sequences for bacteria, whereas the number of sequences ranged from 14,008 to 33,467 with an average of 26,332 sequences for archaea. All sequences were clustered into operational taxonomic units (OTUs) at a $97 \%$ identity threshold. The Shannon's diversity index, Simpson's index, and the Ace and Chao1 estimators were generated for each sample based on the OTU table (Caporaso et al. 2010). The phylogenetic affiliation of each sequence was analyzed using the RDP Classifier (http://rdp.cme.msu.edu/classifier/class_help.jsp\#copynumber) at a confidence level of $80 \%$.

\subsection{Statistical analysis}

PCoA was a method to visualize the similarity and difference of microbial community composition in different environment samples, and the first axis of PCoA represented the principal coordinate component that can explain the microbial data changes maximally. Principal coordinates analysis (PCoA) in Fast UniFrac was used to show the general difference of archaeal community structure among samples based on the relative abundances of the entire archaeal community data. Regression analysis was used to determine variations in soil properties, bacterial and archaeal diversity, and relative abundances of the dominant bacterial and archaeal communities along the peatland vertical profile. Pearson correlation analysis was used to analyze relationships among the soil properties, scores of the first PCoA axis, and the diversity of bacteria and archaea. All statistical analyses were performed in IBM SPSS Statistics 20 (IBM Armonk, New York, U.S.), and the figures were made by the Origin 9.0. Values were considered significant when $\mathrm{p}<0.05$.

\section{Results}

\subsection{Vertical distribution of soil $\mathrm{C}, \mathrm{N}$, and $\mathrm{P}$ concentrations and stoichiometry}

In this study, soil pH ranged from 5.47 to 5.60 and had no significant changes along the soil profile in the Bitahai peatland. With the exception of C: N (Fig. 1d), soil depths significantly influenced the $C, N$, and $P$ concentrations as well as the C:P and N:P ratios $(p<0.05)$. Soil $C$ and $N$ concentrations and $C: P$ and $N: P$ ratios significantly increased (Fig. 1a, b, e, f), but $P$ concentration decreased (Fig. 1C) with increasing soil depth.

\subsection{Vertical pattens of structure and diversity of bacterial and archaeal communities}

The dominant phyla accounting for more than $3 \%$ of the mean relative abundance across all sites and depths for overall bacterial communities were Proteobacteria (39.64\%), Acidobacteria (12.93\%), Chloroflexi (12.81\%), Ignavibacteriae (4.54\%), Planctomycetes (4.21\%), Spirochaetae (3.67\%), and Bacteroidetes (3.23\%) (Fig. 2a). Crenarchaeota (mean relative abundance across all sites and depths of 
$58.67 \%)$, Thaumarchaeota (14.34\%), and Euryarchaeota (10.82\%) were the phyla detected in the archaeal communities (Fig. 2b).

The relative abundances of the dominant bacteria groups significantly changed with soil depth at the phylum and class levels $(p<0.05)$. As depth increasing, relative abundances of Proteobacteria and Acidobacteria significantly decreased, but Spirochaetae, Ignavibacteriae, Chloroflexi, and Planctomycetes significantly increased (Figure S1 a, b, c, d, e, f, g). At the class level, the relative abundances of Betaproteobacteria, Alphaproteobacteria, and Acidobacteria significantly decreased with the peatland depths, while that of Deltaproteobacteria increased (Figure S2 a, b, c, d, e). The relative abundances of dominant archaea phyla also significantly varied with the soil depths $(p<0.01)$. As depth increased, the relative abundance of Crenarchaeota significantly increased (Figure S3 a), but those of Thaumarchaeota and Euryarchaeota significantly decreased (Figure S3 b, c).

Chao1, Ace, and Shannon values were all significantly higher in bacteria than in archaea $(p<0.001)$ (Fig. 3). As increasing soil depths, Chao1 and Ace values of bacteria and archaea show a significant increasing trend (Fig. 3a, b), Shannon values of bacteria and archaea possessed a significant and nonlinear variation trends (Fig. 3c). There was a significant increase in Simpson values of archaea along with soil depths (Fig. 3d).

\subsection{The shifts of methanogen and ammonia-oxidizing microorganisms with soil depths}

Archaeal communities at the order level were analyzed, and the total relative abundance of the methanogenic groups (4.03-11.54\%) significantly decreased with soil depth $\left(R^{2}=0.13, p<0.001\right)$ (Fig. 4). The mean relative abundances of the order Nitrospirales (bacteria) and Nitrososphaerales (archaea) were $2.37 \%$ and $14.34 \%$, respectively. Total relative abundance of ammonia-oxidizing microorganisms also significantly de-creased with soil depth $\left(R^{2}=0.44, p<0.001\right)$ (Fig. 5).

\subsection{Relationships between bacterial, archaeal communities and soil properties}

The PCoA analysis showed that the first principal coordinate axis (PCoA1) explained $39.61 \%$ and $65.84 \%$ of the overall bacterial and archaeal community in our study, respectively. For bacteria community, Pearson correlation analysis showed there was not significant relationships between soil properties and PCoA1, and only soil P correlated significantly and negatively with Ace index (Table 1). For archaea community, PCoA1 was correlated significantly and positively with soil C, N, N:P and C:P, and was significantly and negatively with soil P. Both Chao1 and Ace indexes of archaea were correlated significantly and positively with soil $\mathrm{pH}$ and negatively with $\mathrm{C}$ : $\mathrm{N}$, while soil $\mathrm{C}, \mathrm{N}$ and $\mathrm{N}: \mathrm{P}$ were correlated significantly and positively with archaeal Shannon diversity and negatively with Simpson diversity (Table 2). 
Table 1

Relationships among the score of the first PCoA axis, diversity index and soil properties for bacteria.

\begin{tabular}{|llllll|}
\hline & $\begin{array}{l}\text { Bacteria PCoA 1 } \\
(\mathbf{3 9 . 6 1 \% )}\end{array}$ & Chao & Ace & Shannon & Simpson \\
\hline $\mathrm{pH}$ & -0.335 & 0.123 & 0.152 & -0.030 & 0.324 \\
\hline Total N & 0.287 & 0.116 & 0.129 & -0.132 & -0.064 \\
\hline Total P & -0.090 & -0.307 & $-0.372^{*}$ & -0.018 & -0.110 \\
\hline Total N:P & 0.314 & 0.253 & 0.336 & -0.034 & -0.057 \\
\hline Total C & 0.171 & -0.038 & 0.000 & -0.222 & 0.062 \\
\hline Total C:N & -0.200 & -0.121 & -0.120 & -0.155 & 0.339 \\
\hline Total C:P & 0.117 & 0.057 & 0.139 & -0.129 & 0.163 \\
\hline *. Correlation is significant at the 0.05 level. & & \\
\hline
\end{tabular}

Table 2

Relationships among the score of the first PCoA axis, diversity index and soil properties for archaea.

\begin{tabular}{|llllll|}
\hline & Archaea PCOA1 (65.84\%) & Chao & Ace & Shannon & Simpson \\
\hline $\mathrm{pH}$ & 0.054 & $0.446^{*}$ & $0.451^{*}$ & 0.288 & 0.082 \\
\hline Total N & $0.471^{* *}$ & 0.118 & 0.182 & $-0.640^{* *}$ & $0.563^{* *}$ \\
\hline Total P & $-0.400^{*}$ & -0.036 & -0.058 & 0.069 & -0.169 \\
\hline Total N:P & $0.676^{* *}$ & 0.146 & 0.206 & $-0.546^{* *}$ & $0.561^{* *}$ \\
\hline Total C & $0.404^{*}$ & -0.178 & -0.115 & $-0.599^{* *}$ & $0.426^{*}$ \\
\hline Total C: $N$ & -0.200 & $-0.398^{*}$ & $-0.421^{*}$ & 0.357 & -0.256 \\
\hline Total C:P & $0.406^{*}$ & -0.199 & -0.168 & -0.213 & 0.257 \\
\hline *. Correlation is significant at the 0.05 level ; **. Correlation is significant at the 0.01 level. \\
\hline
\end{tabular}

\section{Discussion}

\subsection{Vertical patterns of bacterial and archaeal communities along soil depths}


As our predicted, this study showed the soil depth had a marked impact on bacterial and archaeal community structures. According to the $16 \mathrm{~S}$ rRNA gene analysis, the dominant groups at the phylum level were Proteobacteria (39.64\%), Acidobacteria (12.93\%), Chloroflexi $(12.81 \%)$ for soil bacterial and were Crenarchaeota, Thaumarchaeota and Euryarchaeota for soil archaea, respectively, which demonstrated that these groups played a key role in the Bitahai peatland. These findings were consistent with many other comprehensive studies on peatland soil bacterial and archaea communities (Rooney-Varga et al. 2007; Seward et al. 2020; Sun et al. 2014).

Usually, Proteobacteria involved in biogeochemical processes in various ecosystems, and was able to promote soil nutrient availability (Fierer et al. 2007). Specifically, such sharp decline of Proteobacteria was reflected in the reduction of the relative abundances of Alphaproteobac-teria, Betaproteobacteria and Deltaproteobacteri at the class level. The decrease in Betaproteobacteria could affect $\mathrm{N}$ cycles as a result of their members displaying metabolic diversities in nitrification (Prosser et al. 2014). Sulfate-reducing bacteria belonging to the class of Deltaproteobacteria, had been shown to mineralize organic carbon (Miyatake et al. 2009). Thus, decreasing trend of the relative abundance of Deltaproteobacteria along soil profiles may represent the decrease of organic carbon mineralization (Chen et al. 2019). Moreover, upper soil layers with low organic carbon content had higher relative abundance of Acidobacteria than deeper soil layers. This was similar for some results have shown that the proportion of Acidobacteria in degraded wetland soil with low organic matter content was high (Peralta et al. 2013). In addition, there was a significantly increasing trend in abundance of Chloroflexi along soil profiles. It has been detected in a wide range of anaerobic habitats, and plays an important role in degrading complex polymeric organic compounds into low molecular weight substrates (Speirs et al. 2019). Previous study also manifested that Chloroflexi was survive in nutrient deprived environment (Wu et al. 2021), thus were more abundant under nutrient limitations (Hug et al. 2013). Therefore, the significant vertical change of these predominant groups in soil microorganisms meant soil depths would profoundly alter $\mathrm{C}$ and $\mathrm{N}$ and cycles in the Bitahai peatland.

Furtherly, the functional microbial groups related to pivotal process of $\mathrm{C}$ and $\mathrm{N}$ cycle obviously were impacted by soil depths (Figs. 4 and 5). Specifically, the total relative abundance of the methanogenic groups significantly decreased with soil depth (Fig. 4), demonstrating would be restrain the methane production of the deeper layers. Methanotrophs play an important role in mitigating the release of the greenhouse gas methane (Liebner and Svenning 2013). Most methanotrophs belong to Proteobacteria, three families Methylococcaceae, Methylocystaceae, and Beijerinckiaceae are methanotrophs (Dworkin et al. 2006; Liebner et al. 2009). The decreasing trends of above three kinds thus may represent the reduction of aerobic methane oxidation with soil depths (Table S1). The ammonia-oxidizing microorganisms included Nitrospirales (bacteria) and Nitrososphaerales (archaea) and their mean relative abundances also significantly decreased with soil depth (Fig. 5), which meant a weak ammoniaoxidizing process may exist in deeper soil layers (Prosser et al. 2014). The significant vertical decline in relative abundance of methanogenic, methanotrophs and ammonia-oxidizing microorganisms probably suggested the deeper soil layers had a low intensity of methane production, oxidation and nitrification processes in the Bitahai peatland. 
In present study, there was a higher bacterial richness, evenness, and diversity compared with archaea. This result was consistent with studies performed on peatlands (Basiliko et al. 2013), anaerobic sediments of a soda lake (Rojas et al. 2018) and a deep-sea mud volcano (peatlands et al. 2011). Compared with some studies by report from Zoige peatlands (Zhong et al. 2017), both Chao1 and Ace values significantly increased with soil depths in the Bitahai peatlands. Our results further showed that Shannon in bacterial and Simpson in archaeal increased while Shannon in archaeal decreased with soil depths. The observed similar and obvious increasing vertical trends of diversity prokaryotic communities suggested prokaryotic diversity also played a pivotal role in peatland functions at deep soil layer. Based on the above results, therefore, our study indeed found soil depth significantly influenced the structure and diversity of bacterial and archaeal in Bitahai peatland, supporting our first hypothesis.

\subsection{Relationship between bacterial and archaeal communities and soil properties along soil profiles}

Our study clearly shown that various soil depths existed a distinct prokaryotic structure and diversity (Figs. 2 and 3). These vertical patterns essentially were able to reflecting the environmental factors variation with soil depths (e.g., physicochemical properties and oxygen limitations) (Lamit et al. 2017; Zhong et al. 2017). The relative abundance of aerobic (Proteobacteria and Acidobacteria) and anaerobes microbes (Chloroflexi and Planctomyctes) decreased and increased with increasing depths (Figure S2). This indicated that upper soil layers were dominated by aerobic processes while deeper soil layers by anaerobic processes in Bitahai peatlands. These results were identical to the previous work from Zoige peatlands (Zhong et al. 2017). Such opposite trends of aerobic and anaerobes prokaryotic along soil profiles may be explained by changes of soil water contents and oxygen limitations (Fierer et al. 2003). $\mathrm{C}: \mathrm{P}$ and $\mathrm{N}: \mathrm{P}$ in soil were general negative correlated with nutrients mineralization rate and availability (Hu et al. 2019; Ren et al. 2016; Shen et al. 2019). Higher C:P and N:P ratios in deep soil layers (Fig. 1e and f) implied the relatively poor nutrients status. The abundance of Chloroflexi was positive correlated to soil $\mathrm{N}: P$ ratio with increasing change along soil profiles (Fig. 1e and S4). These results possibly caused an opposite vertical trend of copiotrophic (i.e., Proteobacteria) and oligotrophic bacteria (i.e., Chloroflexi) along soil profiles. More precisely, Proteobacteria would deplete while Chloroflexi would enrich in the deeper soil layers of Bitahai peatlands (Figure S2 a, f).

It was very interesting that bacterial diversity was not related to mostly soil properties except soil $\mathrm{P}$ (Table 1). This result suggests that other underlying environmental factors instead of soil properties may drive the bacterial diversity in the Bitahai peatland. Previous studies have shown that climatic factors such as temperature, soil moisture (Stres et al. 2008), and water table (Zhong et al. 2017) can influence soil bacterial communities in the peatland ecosystem. Other studies also highlighted that climatic factors had unexpectedly strong impacts on the soil bacterial community composition and variation (Zheng et al. 2020). In the present study, Bitahai peatland is saturated throughout the year, and this makes it very unlikely that soil moisture or water table could be undetected drivers of microbial diversity. In light of the above, despite lacking of more measurement, there was a reason to speculate these un-attended climatic factors perhaps regulate bacterial communities' diversity along the soil profile in the Bitahai peatland. In 
order to better understand the distribution of bacterial communities along this soil profile, it is urgently needed to further explore the drivers of bacterial communities along the soil depths in the Bitahai peatland. Furthermore, only soil $\mathrm{P}$ had a negative effect on the Bitahai peatland bacterial richness. This means natural and human activities that cause changes in soil phosphorus could affect bacterial richness in the future (Zheng et al. 2020).

Archaeal community structure was markedly impacted by soil $\mathrm{C}, \mathrm{N}$, and $\mathrm{P}$ concentrations and stoichiometric ratios along the peatland profile (Table 2). It was consistent with previous studies that had shown that soil C, N, and P (Bergkemper et al. 2016) and elemental stoichiometry (Shen et al. 2019) are drivers for microbial community structure. Our findings also showed that changes in soil physicochemical characteristics (e.g., pH, TC, TN, C: N and N:P) with depth had significant positive or negative correlations with the archaeal richness and diversity (Table 2). These results were similar with some previous works documented that the changes in prokaryotic diversity were probably attributable to the differences in physicochemical properties (Pachiadaki et al. 2011; Wu et al. 2021; Zhong et al. 2017), and thus partly supported our second hypothesis. It follows that the effects of soil C, N and P content and stoichiometry on community diversity were distinct between bacteria and archaea. Namely, soil properties associated with peatland depths have a stronger influence on community structure and diversity in archaea, not in bacteria. These findings suggested that above difference should be taken into consideration in the future works and model prediction of peatland. Additionally, dominant taxa abundance and diversity apparently increased in archaea while decreased in bacteria. Therefore, our study also highlighted that archaea community may play an increasingly vital role in biogeochemistry cycling for deeper peatland soil layers.

\section{Conclusions}

Soil depth can affect the relative abundance of $\mathrm{C}$ and $\mathrm{N}$ related microbes. As increasing soil depth, the relative abundance of methanotrophic bacteria, methanogenic groups and the ammonia-oxidizing microorganisms decreased. These higher levels of such functional groups indicated some key processes of soil $\mathrm{C}$ and $\mathrm{N}$ cycle may be more active in the upper layers. Bacterial richness, evenness, and diversity were higher compared with archaea, while their vertical changing trends were consistent. Across soil profiles, $\mathrm{C}, \mathrm{N}$, and $\mathrm{P}$ concentrations and their stoichiometric ratios did markedly impact the community structure and diversity for archaeal, but were not for bacteria in the Bitahai peatland. Our results highlighted the microbial community structure and diversity depended on soil depths, and the affecting factors for bacteria and archaea were different in Bitahai peatland.

\section{Declarations}

\section{Ethical Approval and Consent to Participate}

Not applicable. 


\section{Consent to Publish}

Not applicable.

\section{Authors Contributions}

WL, DFF and BH conceived and designed the study; MML and RS collected the data; ZAY and HC contributed field sampling; DFF performed the analysis; WL and BH wrote the paper.

\section{Availability of data and materials}

All data generated or analyzed during the current study are included in this article and its supplementary information files.

\section{Acknowledgments}

This study was financially supported by the Thousand Talents Program of Yunnan Province for Young Talents supporting Dr. W. Li (YNQR-QNRC-2018-089), the Programs of Science and Technology Department Foundation of Yunnan Province (2018FD007 and 2018BC001), the National Natural Science Foundation of China (31700411).

\section{Conflict of interest}

The authors declare no competing interests.

\section{References}

1. Andersen R, Chapman SJ, Artz RRE (2013) Microbial communities in natural and disturbed peatlands: A review. Soil Biol Biochem 57:979-994. doi:https://doi.org/10.1016/j.soilbio.2012.10.003

2. Basiliko N, Henry K, Gupta V, Moore TR, Driscoll BT, Dunfield PF (2013) Controls on bacterial and archaeal community structure and greenhouse gas production in natural, mined, and restored Canadian peatlands. Front Microbiol 4. http:// doi:10.3389/fmicb.2013.00215

3. Bergkemper F, Welzl G, Lang F, Krueger J, Schloter M, Schulz S (2016) The importance of C, N and P as driver for bacterial community structure in German beech dominated forest soils. J Plant Nutr Soil Sc 179:472-480

4. Blume E, Bischoff M, Reichert JM, Moorman T, Konopka A, Turco RF (2002) Surface and subsurface microbial biomass, community structure and metabolic activity as a function of soil depth and season. Appl Soil Ecol 20:171-181 
5. Cadillo-Quiroz H, Brauer S, Yashiro E, Sun C, Yavitt J, Zinder S (2006) Vertical profiles of methanogenesis and methanogens in two contrasting acidic peatlands in central New York State, USA. Environ Microbiol 8:1428-1440

6. Caporaso JG et al. (2010) QIIME allows analysis of high-throughput community sequencing data. Nat Methods 7:335-336

7. Caporaso JG et al. (2012) Ultra-high-throughput microbial community analysis on the Illumina HiSeq and MiSeq platforms. ISME J 6:1621-1624

8. Chen D et al. (2019) Effects of aridity on soil microbial communities and functions across soil depths on the Mongolian Plateau. Funct Ecol 33:1561-1571

9. Dinsmore KJ, Skiba UM, Billett MF, Rees RM, Drewer J (2009) Spatial and temporal variability in $\mathrm{CH} 4$ and N2O fluxes from a Scottish ombrotrophic peatland: Implications for modelling and up-scaling. Soil Biol Biochem 41:1315-1323

10. Dise NB (2009) Peatland Response to Global Change. Science 326:810-811

11. Dworkin M, Falkow S, Rosenberg E, Schleifer KH, Stackebrandt E (2006) The Prokaryotes II The Methanotrophs - The Families Methylococcaceae and Methylocystaceae. http:// 10.1007/0-38730745-1:266-289

12. Eilers KG, Debenport S, Anderson S, Fierer N (2012) Digging deeper to find unique microbial communities: The strong effect of depth on the structure of bacterial and archaeal communities in soil. Soil Biol Biochem 50:58-65

13. Fierer N, Bradford MA, Jackson RB (2007) Toward an ecological classification of soil bacteria. Ecology 88:1354-1364. doi:10.1890/05-1839

14. Fierer N, Schimel JP, Holden PA (2003) Variations in microbial community composition through two soil depth profiles. Soil Biol Biochem 35:167-176

15. Godin A, McLaughlin JW, Webster KL, Packalen M, Basiliko N (2012) Methane and methanogen community dynamics across a boreal peatland nutrient gradient. Soil Biol Biochem 48:96-105

16. He S, Li W, Cheng X, Tan R, Song W (2019) The effect of trampling disturbance on functional traits, species diversity, and functional diversity of alpine meadows in Bitahai Nature Reserve. Acta Ecologica Sinica 39:2063-2070

17. Hoyt AM, Gandois L, Eri J, Kai FM, Harvey CF, Cobb AR (2019) CO2 emissions from an undrained tropical peatland: Interacting influences of temperature, shading and water table depth. Global Change Biol 25:2885-2899

18. Hu L, Ade L, Wu X, Zi H, Luo X, Wang C (2019) Changes in Soil C:N:P Stoichiometry and Microbial Structure along Soil Depth in Two Forest Soils. Forests. https://doi:10.3390/f10020113

19. Huai Wx, Tian G, Hansen EM, Zhao Wx, Goheen EM, Gruenwald NJ, Cheng C (2013) Identification of Phytophthora species baited and isolated from forest soil and streams in northwestern Yunnan province, China. Forest Pathol 43:87-103 
20. Hug LA et al. (2013) Community genomic analyses constrain the distribution of metabolic traits across the Chloroflexi phylum and indicate roles in sediment carbon cycling. Microbiome 1 doi:10.1186/2049-2618-1-22

21. Jeanbille M, Buee M, Bach C, Cebron A, Frey-Klett P, Turpault MP, Uroz S (2016) Soil Parameters Drive the Structure, Diversity and Metabolic Potentials of the Bacterial Communities Across Temperate Beech Forest Soil Sequences. Microb Ecol 71:482-493

22. Koranda $\mathrm{M}$ et al. (2011) Microbial processes and community composition in the rhizosphere of European beech - The influence of plant $C$ exudates. Soil Biol Biochem 43:551-558

23. Laiho R (2006) Decomposition in peatlands: Reconciling seemingly contrasting results on the impacts of lowered water levels. Soil Biol Biochem 38:2011-2024

24. Lamit LJ et al. (2017) Patterns and drivers of fungal community depth stratification in Sphagnum peat. Fems Microbiol Ecol. https://doi:10.1093/femsec/fix082

25. Li C, Yan K, Tang L, Jia Z, Li Y (2014) Change in deep soil microbial communities due to long-term fertilization. Soil Biol Biochem 75:264-272

26. Liebner S, Rublack K, Stuehrmann T, Wagner D (2009) Diversity of Aerobic Methanotrophic Bacteria in a Permafrost Active Layer Soil of the Lena Delta, Siberia. Microb Ecol 57:25-35

27. Liebner S, Svenning MM (2013) Environmental Transcription of mmoX by Methane-Oxidizing Proteobacteria in a Subarctic Palsa Peatland. Appl Environ Microbiol 79:701-706

28. Lin X et al. (2014) Microbial Community Stratification Linked to Utilization of Carbohydrates and Phosphorus Limitation in a Boreal Peatland at Marcell Experimental Forest, Minnesota, USA. Appl Environ Microbiol 80:3518-3530

29. Liu B, Talukder MJH, Terhonen E, Lampela M, Vasander H, Sun H, Asiegbu F (2020) The microbial diversity and structure in peatland forest in Indonesia. Soil Use Manage 36:123-138

30. Liu $\mathrm{Z}$ et al. (2020b) Effect of simulated acid rain on soil $\mathrm{CO}_{2}, \mathrm{CH}_{4}$ and $\mathrm{N}_{2} \mathrm{O}$ emissions and microbial communities in an agricultural soil. Geoderma 366. doi:10.1016/j.geoderma.2020.114222

31. Magoc T, Salzberg SL (2011) FLASH: fast length adjustment of short reads to improve genome assemblies. Bioinformatics 27:2957-2963

32. Martinez CE, Yanez C, Yoon S-j, Bruns MA (2007) Biogeochemistry of metalliferous peats: Sulfur speciation and depth distributions of dsrAB genes and $\mathrm{Cd}, \mathrm{Fe}, \mathrm{Mn}, \mathrm{S}$, and $\mathrm{Zn}$ in soil cores. Environ Sci Technol 41:5323-5329

33. Miyatake T, MacGregor BJ, Boschker HTS (2009) Linking Microbial Community Function to Phylogeny of Sulfate-Reducing Deltaproteobacteria in Marine Sediments by Combining Stable Isotope Probing with Magnetic-Bead Capture Hybridization of 16S rRNA. Appl Environ Microb 75:4927-4935

34. Pachiadaki MG, Kallionaki A, Dahlmann A, De Lange GJ, Kormas KA (2011) Diversity and Spatial Distribution of Prokaryotic Communities Along A Sediment Vertical Profile of A Deep-Sea Mud Volcano. Microb Ecol 62:655-668 
35. Peralta RM, Ahn C, Gillevet PM (2013) Characterization of soil bacterial community structure and physicochemical properties in created and natural wetlands. Sci Total Environ 443:725-732

36. Prosser J.I., Head I.M., Stein L.Y. (2014) The Family Nitrosomonadaceae. In: Rosenberg E., DeLong E.F., Lory S., Stackebrandt E., Thompson F. (eds) The Prokaryotes. Springer, Berlin, Heidelberg. https://doi.org/10.1007/978-3-642-30197-1_372

37. Putkinen A, Juottonen H, Juutinen S, Tuittila E-S, Fritze H, Yrjala K (2009) Archaeal rRNA diversity and methane production in deep boreal peat. Fems Microbiol Ecol 70:87-98

38. Ren $\mathrm{C}$ et al. (2016) Linkages of C:N:P stoichiometry and bacterial community in soil following afforestation of former farmland. Forest Ecol Manag 376:59-66

39. Rojas P, Rodriguez N, de la Fuente V, Sanchez-Mata D, Amils R, Sanz JL (2018) Microbial diversity associated with the anaerobic sediments of a soda lake (Mono Lake, California, USA). Can J Microbiol 64:385-392

40. Rooney-Varga JN, Giewat MW, Duddleston KN, Chanton JP, Hines ME (2007) Links between archaeal community structure, vegetation type and methanogenic pathway in Alaskan peatlands. Fems Microbiol Ecol 60:240-251

41. Saari P, Saarnio S, Heinonen J, Alm J (2013) Emissions and dynamics of $\mathrm{N}_{2} \mathrm{O}$ in a buffer wetland receiving water flows from a forested peatland. Boreal Environ Res 18:164-180

42. Seward J et al. (2020) Peatland Microbial Community Composition Is Driven by a Natural Climate Gradient. Microb Ecol. https://doi:10.1007/s00248-020-01510-z

43. Shen $\mathrm{F}$ et al. (2019) Soil N/P and C/P ratio regulate the responses of soil microbial community composition and enzyme activities in a long-term nitrogen loaded Chinese fir forest. Plant Soil 436:91-107

44. Shu S-S, Chen F-Z, Yang J-X, Yang X-J, Chen X-Y (2013) Diversity and faunal analysis of crustaceans in Potatso National Park, Shangri-La. Zool Res 34:204-208

45. Speirs LBM, Rice DTF, Petrovski S, Seviour RJ (2019) The Phylogeny, Biodiversity, and Ecology of the Chloroflexi in Activated Sludge. Front Microbiol. https:// doi:10.3389/fmicb.2019.02015

46. Stres B et al. (2008) Influence of temperature and soil water content on bacterial, archaeal and denitrifying microbial communities in drained fen grassland soil microcosms. Fems Microbiol Ecol 66:110-122

47. Sun H, Terhonen E, Koskinen K, Paulin L, Kasanen R, Asiegbu FO (2014) Bacterial diversity and community structure along different peat soils in boreal forest. Appl Soil Ecol 74:37-45

48. Tsitko I, Lusa M, Lehto J, Parviainen L, Ikonen ATK, Lahdenperfi A-M, Bomberg M (2014) The Variation of Microbial Communities in a Depth Profile of an Acidic, Nutrient-Poor Boreal Bog in Southwestern Finland. Open J Ecol:832-859. http://doi:10.4236/oje.2014.413071

49. Vissers EW, Bodelier PLE, Gerard M, Laanbroek HJ (2010) A nested PCR approach for improved recovery of archaeal 16S rRNA gene fragments from freshwater samples. Fems Microbiol Lett 298:193-198 
50. Walters W et al. (2016) Improved Bacterial 16S rRNA Gene (V4 and V4-5) and Fungal Internal Transcribed Spacer Marker Gene Primers for Microbial Community Surveys. Msystems 1:e0000900015

51. Wang M, Tian J, Bu Z, Lamit LJ, Chen H, Zhu Q, Peng C (2019) Structural and functional differentiation of the microbial community in the surface and subsurface peat of two minerotrophic fens in China. Plant Soil 437:21-40

52. Wang S, Guo X, Yu L, Liu S, Wang X, Tang S, Tian W (2017) Soil Nutrient and Nitrous Oxide Flux of Bita Lake Peat Bogs under Influence of Yak Grazing. Wetland Science 15:244-249

53. Wang $Z$ et al. (2020) Compositional and functional responses of soil microbial communities to longterm nitrogen and phosphorus addition in a calcareous grassland. Pedobiologia. https:// doi:10.1016/j.pedobi.2019.150612

54. Wu G, Gao Y, Wang Y, Wang Y, Xu D (2015) Land-use/land cover changes and their driving forces around wetlands in Shangri-La County, Yunnan Province, China. Int J Sust Dev World 22:110-116

55. Wu Y et al. (2021) Variations in the diversity of the soil microbial community and structure under various categories of degraded wetland in Sanjiang Plain, northeastern China. Land Degrad Dev doi:10.1002/ldr.3872

56. Xu Y, Wang H, Xiang X, Wang R, Tian W (2019) Vertical Variation of Nitrogen Fixers and Ammonia Oxidizers along a Sediment Profile in the Dajiuhu Peatland, Central China. J Earth Sci 30:397-406

57. Yu Z, Loisel J, Brosseau DP, Beilman DW, Hunt SJ (2010) Global peatland dynamics since the Last Glacial Maximum. Geophys Res Lett. https:doi:10.1029/2010gl043584

58. Zhang T, Gu ZJ (2005) A new basic chromosome number of $x=7$ for the genus Streptopus (Liliaceae). Acta Phytotaxonomica Sinica 43:533-538

59. Zheng Y, Ji N-N, Wu B-W, Wang J-T, Hu H-W, Guo L-D, He J-Z (2020) Climatic factors have unexpectedly strong impacts on soil bacterial beta-diversity in 12 forest ecosystems. Soil Biol Biochem. https://doi:10.1016/j.soilbio.2019.107699

60. Zhong Q et al. (2017) Water table drawdown shapes the depth-dependent variations in prokaryotic diversity and structure in Zoige peatlands. Fems Microbiol Ecol. https:// doi:10.1093/femsec/fix049

61. Zhou W, Chen BK (2006) Biodiversity of Bitahai Nature Reserve in Yunnan Province, China. Biodivers Conserv 15:839-853

62. Zhou X, Zhang Z, Tian L, Li X, Tian C (2017) Microbial communities in peatlands along a chronosequence on the Sanjiang Plain, China. Sci Rep-uk. http://doi:10.1038/s41598-017-10436-5

63. Zhu B, van Dijk G, Fritz C, Smolders AJP, Pol A, Jetten MSM, Ettwig KF (2012) Anaerobic Oxidization of Methane in a Minerotrophic Peatland: Enrichment of Nitrite-Dependent Methane-Oxidizing Bacteria. Appl Environ Microbiol 78:8657-8665

\section{Figures}



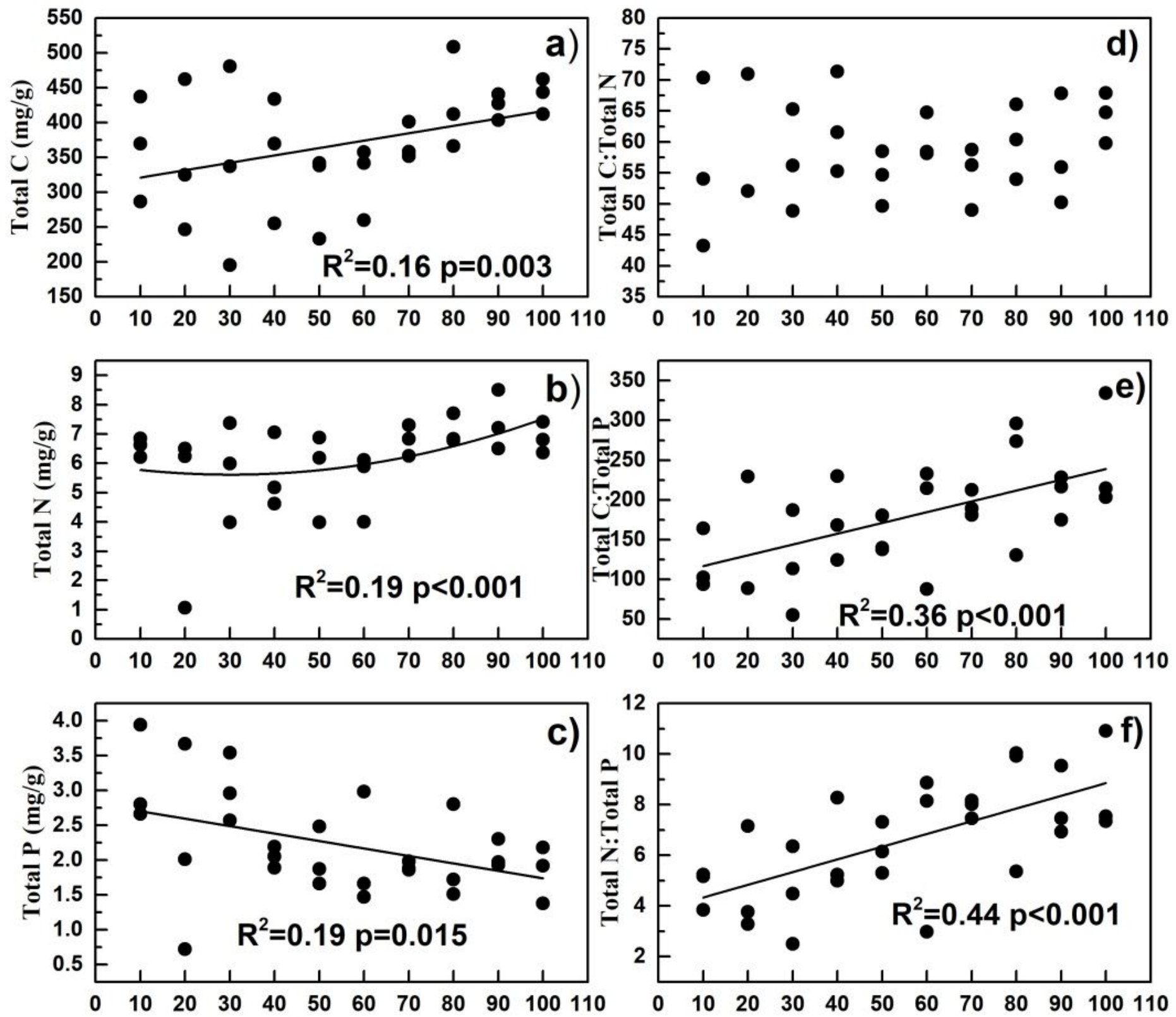

Depth (cm)

Depth (cm)

Figure 1

Vertical distribution of soil C, N, and P concentrations and stoichiometry 
(a)

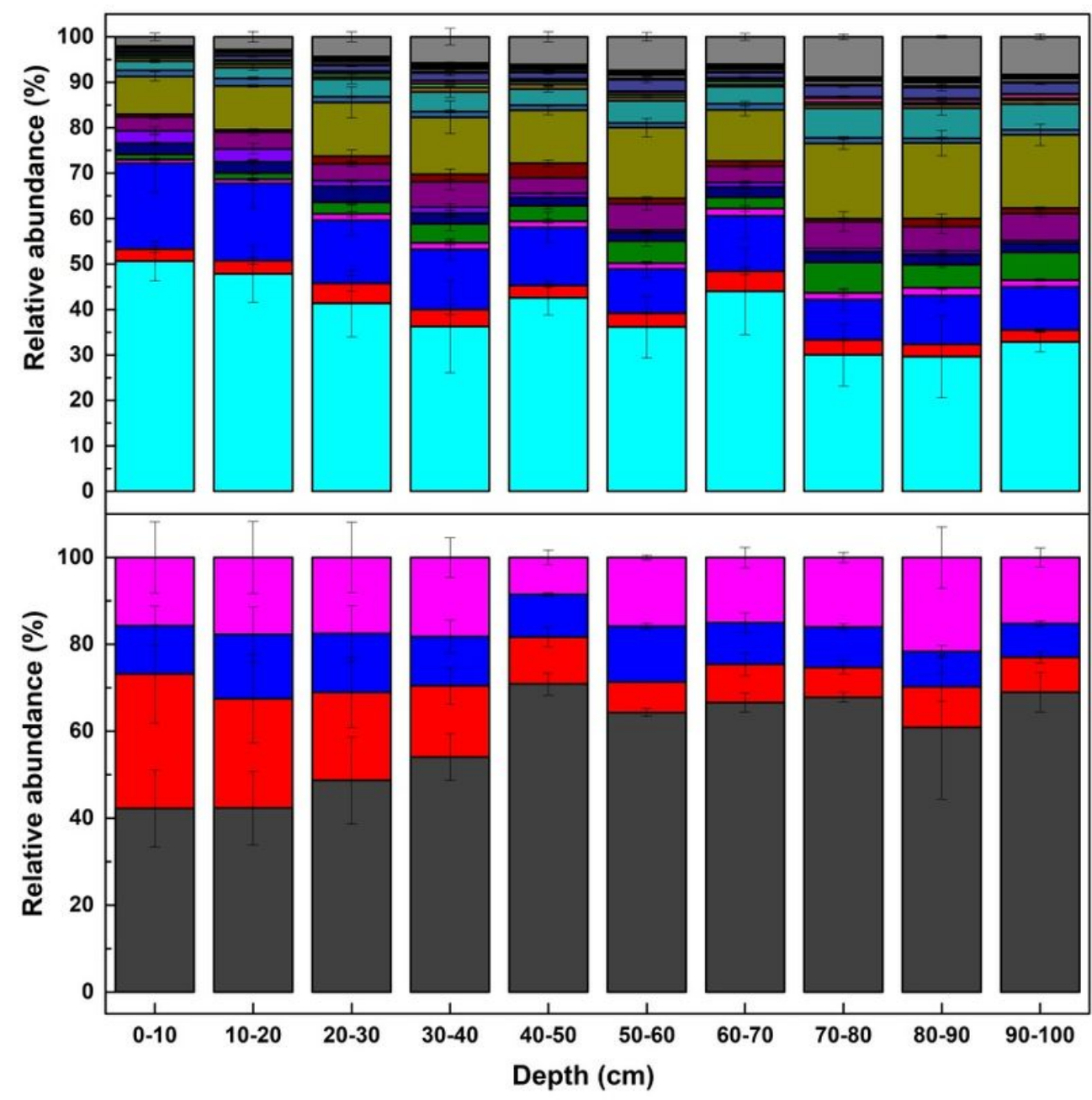

Figure 2

Vertical pattens of structure and diversity of bacterial and archaeal communities $\square$ Other

$\square$ Armatimonadetes $\square$ Parcubacteria

$\square$ Hydrogenedentes

$\square$ Chlorobi

$\square$ DeinococcusThermus

$\square$ Candidatus Levybacteria

$\square$ Elusimicrobia

Candidatus Woesebacteria

Omnitrophica

$\square$ Candidatus Amesbacteria

$\square$ Fibrobacteres

$\square$ Latescibacteria

Gemmatimonadetes

$\square$ Planctomycetes

$\square$ Verrucomicrobia

$\square$ Chloroflexi

$\square$ Firmicutes

$\square$ Ignavibacteriae

$\square$ Actinobacteria

- Nitrospirae

$\square$ Spirochaetae

$\square$ Aminicenantes

Acidobacteria

$\square$ Bacteroidetes

$\square$ Proteobacteria

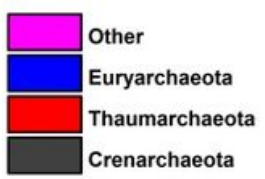



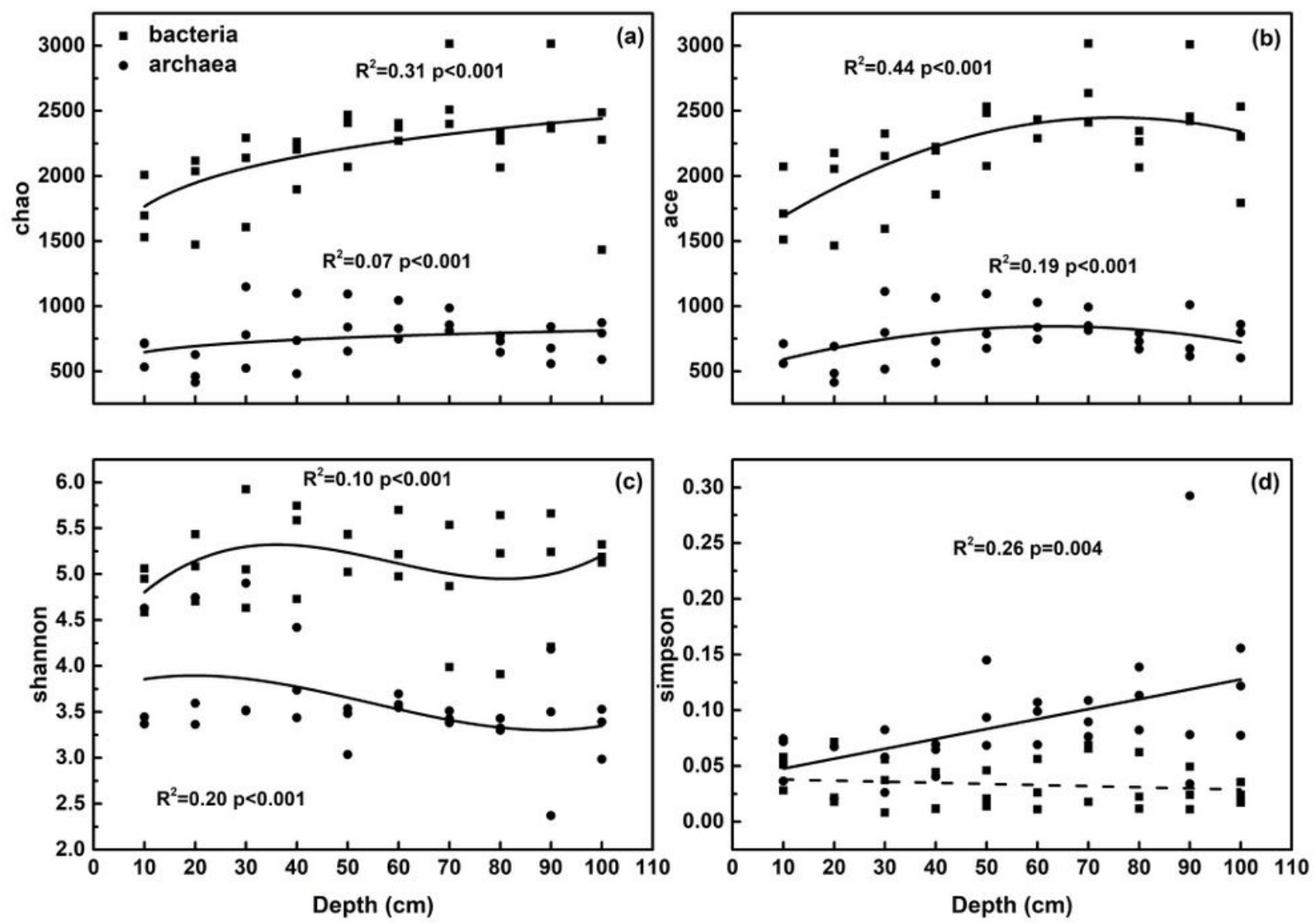

Figure 3

Chao1, Ace, and Shannon values were all significantly higher in bacteria than in archaea $(p<0.001)$ (Figure 3). As increasing soil depths, Chao1 and Ace values of bacteria and archaea show a significant increasing trend (Figure $3 \mathrm{a}, \mathrm{b}$ ), Shannon values of bacteria and archaea possessed a significant and non-linear variation trends (Figure 3c). There was a significant increase in Simpson values of archaea along with soil depths (Figure 3d). 


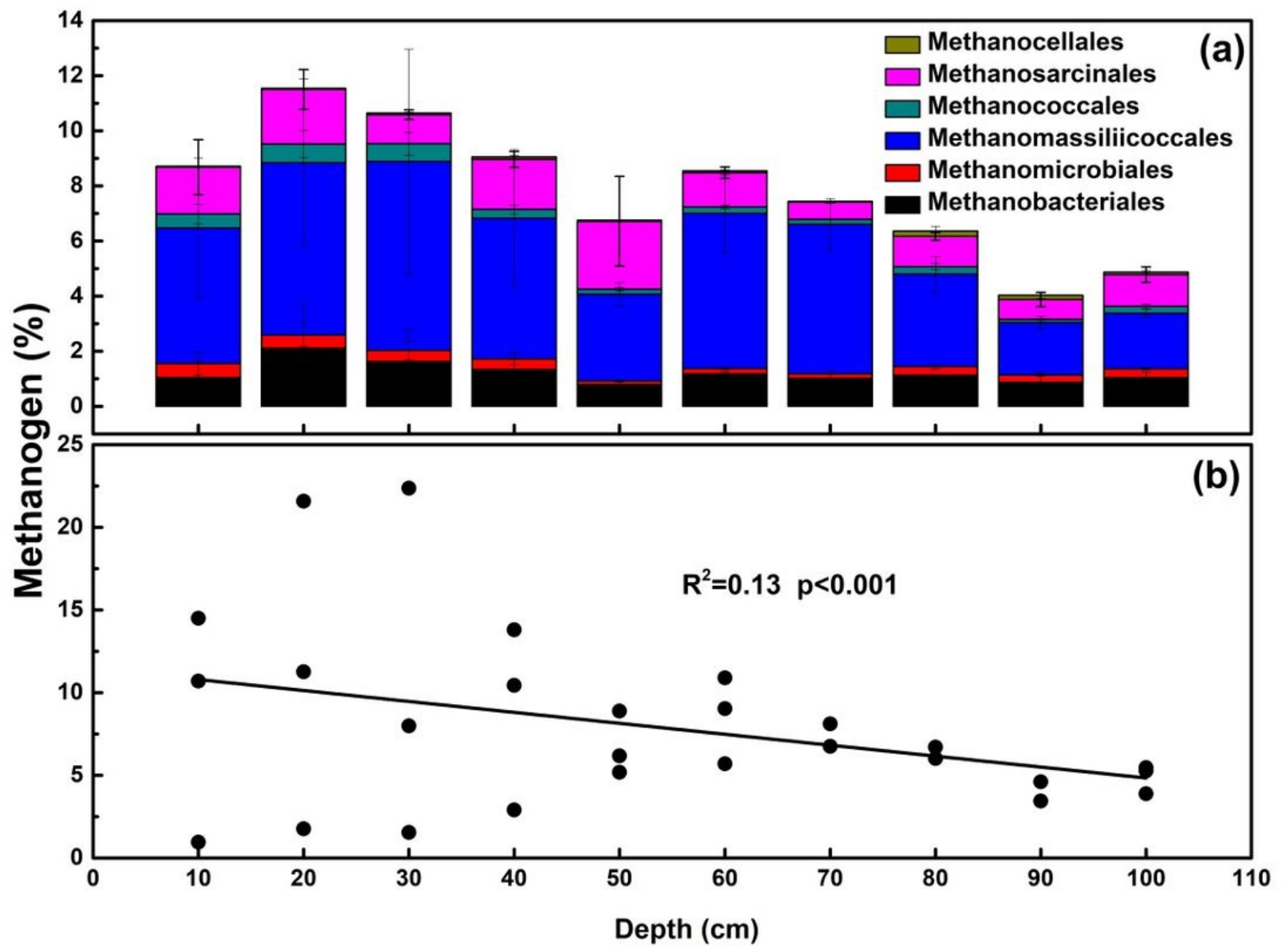

Figure 4

Archaeal communities at the order level were analyzed, and the total relative abundance of the methanogenic groups $(4.03-11.54 \%)$ significantly decreased with soil depth ( $R 2=0.13, p<0.001)$ (Figure 4). 


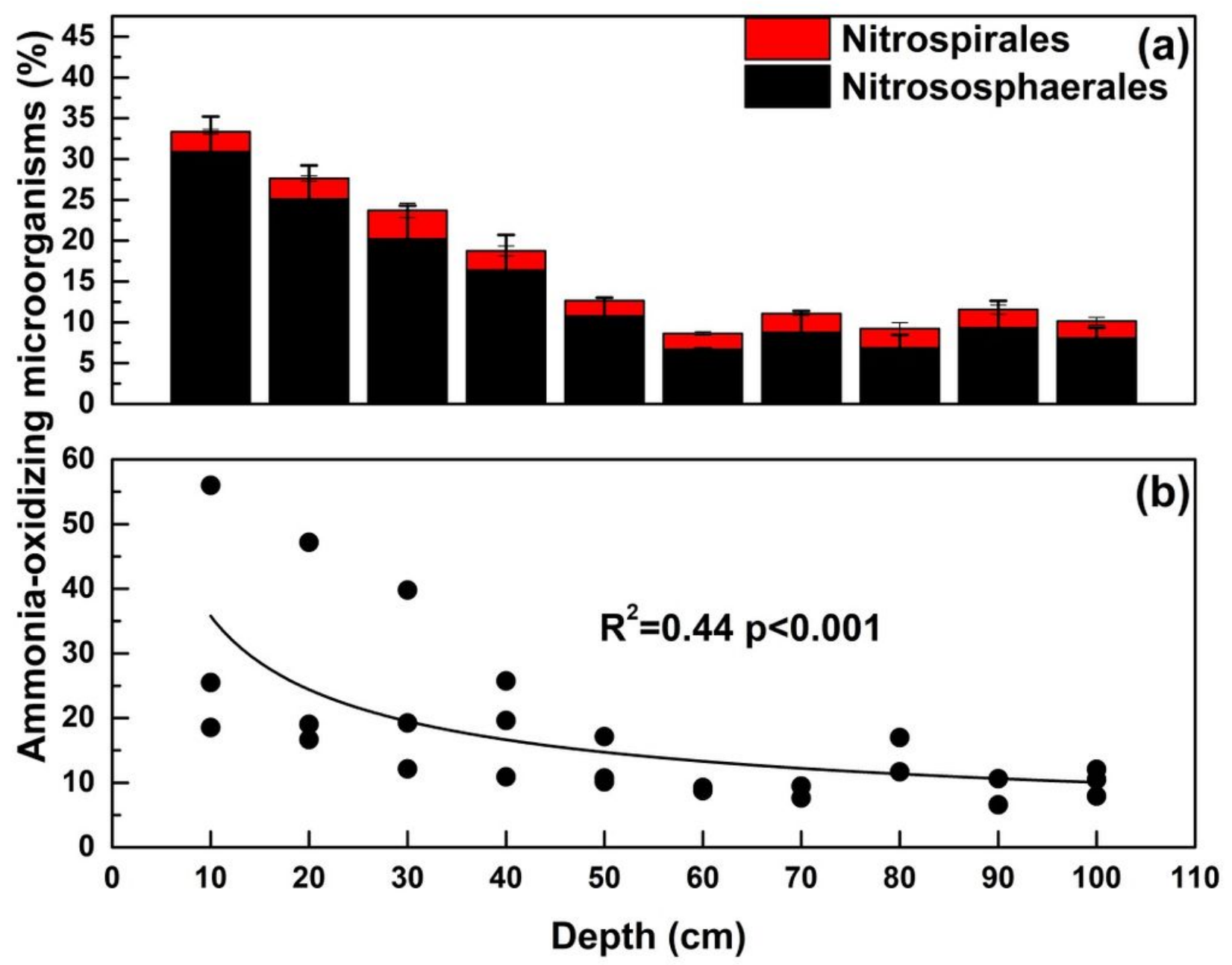

Figure 5

Total relative abundance of ammonia-oxidizing microorganisms also significantly de-creased with soil depth $(R 2=0.44, p<0.001)$ (Figure 5).

\section{Supplementary Files}

This is a list of supplementary files associated with this preprint. Click to download.

- SupplementaryMaterial.docx 